\title{
THE ENVIRONMENTAL THERMAL COMFORT ANALYSIS OF PUBLIC SPACE IN JETAYU PARK, PEKALONGAN CITY
}

\author{
Rhisa Aidilla SUPRAPTO', Ani Hastuti ARTHASARI ${ }^{1}$
}

DOI: $10.21163 / G T \_2020.151 .32$

\begin{abstract}
:
The study examined the thermal conditions in Jetayu Park, Pekalongan City. Pekalongan city is known as the City of Coast with high temperatures, so the impact on the inconvenience of outdoor activities, especially in the daytime. On the other hand, the City Government is trying to increase public space as a green space function to improve the microclimate in Pekalongan City. Jetayu Park was chosen as a case study because the site is in a strategic position and a high level of use compared to four other public spaces. In this study, a field survey conducted in May 2019, which was a transitional month between the dry season and the rainy season. Observation of the activities of the use of Jetayu Park was carried out in the morning, afternoon, and evening. Besides, observation of the velocity, humidity, and air temperature also done using the Envirometer to find out the thermal conditions in the area. The results show that during the daytime activities at Jetayu Park are very few when compared to morning and evening. It is also reinforced by thermal condition measurement data, which shows conditions during the day do not meet thermal comfort.
\end{abstract}

Key-words: Envirometer Microclimate, Public Space, Thermal Comfort, Sustainable.

\section{INTRODUCTION}

Nowadays, cities in Indonesia have limitations in meeting the public space for citizens to express, interact, communicate, and transact. Generally, what happens in the cities in Indonesia is experiencing a deficit because the amount of public space provided by the City Government has not been able to facilitate the needs of various social activities that should be the rights of its citizens. Learning from the city of Surabaya in promoting the development of green open space since 2008 turned out to have a significant influence on the decline in air temperatures in the city. It is evidenced by air measurement using an air quality indicator tool, where the average temperature of the City of Surabaya has fallen from 30-31 degrees Celsius to 28-29 degrees Celsius (Kompas, 2019). Mean while, in the tropical cities, due to the abundant solar radiation and the relatively high air temperature and relative humidity levels, long periods of outdoor thermal discomfort are common. Considering also the impact of urban heat island (UHI) effects in the urban areas, the need for designing outdoor spaces for outdoor comfortable criteria is critical (Amirhosein et al., 2019)

A city should provide a minimum of $9 \mathrm{~m}^{2}$ of green spaces for each person based ond the requirement from World Health Organization-WHO, to ensure the adequate amount of urban green spaces for enhancing people's quality of life (Suthat et al., 2019). Pekalongan City like other developing cities struggling to provide the need of green spaces (Tab. 1). There are now several public spaces that also have a function as green spaces.

\footnotetext{
${ }^{1}$ University of Amikom Yogyakarta, Faculty of Science and Technology, 55283 Yogyakarta, Indonesia, Corresponding author : rhisaaidilla@amikom.ac.id
} 
The local government has developed it into creative public spaces. One of them is public space in the Jetayu area, where the location is in District Panjang in the north of Pekalongan City. The green space with a total area of about 1.16 hectares, divided into active and passive parks (Alkadri, 2014). An alive park, with big yard and grass which has edges with pavement and is surrounded by quite shady trees. Along the sidewalk, there is also some street furniture such as flower pots, lighting lamps, flagpoles, and billboards. Around the park, several street vendors sell street food and stuff from early morning to evening. Pekalongan City Government not only intends to increase the amount of green open space in the city but also to make public space with the approach of the creative space concept. It aims to strengthen Pekalongan City's branding as a Creative City on the north coast of the island of Java. The public open spaces that have been developed by the Government of Pekalongan City include Monument '45 Park, Jetayu Park, Pekalongan City Hall Green Space, Alun-Alun Nusantara, Sorogenen Park. When compared between the five city parks, it concluded that Jetayu Field is a public green open space which plays the most important role for Pekalongan City compared to other parks. It is due to the high intensity of activities carried out in this region, including the celebration of national and international batik week festival, the commemoration day of national technology. Besides, Jetayu Park is also surrounded by valuable buildings. Such as the Batik Museum, Al Ikhlas Mosque, the Indonesian Christian Church, St. Peter's Church, Pekalongan Post Office, Mylpaal Monument (a marker believed to be the zero point of the island of Java), GOR Jetayu, up to the Loji bridge.

The Pekalongan City Government is quite active in making improvements to meet the needs of public open space. This stressed by the Mayor of Pekalongan conveying in one of his speeches that there were still many Pekalongan City Communities who complained about public space. Moreover, his party took the initiative to add public space, and then he developed into a revolutionary movement to build a comfortable public space for the community. While relating to aspects of 'thermal comfort' actually has dominated human life, especially in terms of interacting with the physical environment. It dramatically affected the existence of public space. Most people talk about their thermal sensations about the air around them, such as 'too hot' or 'too cold,' or maybe just saying that at some point they feel 'hot,' 'cold,' and so on. It shows that the aspect of thermal comfort is very influential in everyday life.

\section{STUDY AREA}

\section{Green Open Space}

The rapid development of urban areas in cities in Southeast Asia has an impact on increasing the ecological burden of the urban areas. One most visible thing is the change of green land into built land, which then contributes to the vulnerability of climate change (Beta \& Wayan, 2019; Gunawan et al., 2015; Yusuf \& Francisco, 2009; Manik \& Syaukat, 2015; Kalnay \& Cai, 2003). The existence of green open space The public can be a supporter of the realization of healthy settlements, wherein government regulations it has also been required for urban areas to have a public space with an area of at least $20 \%$ of the downtown area. Without green open space, the microclimate in an urban village can be affected. There is no green open space as a source of oxygen, causing poor and imperfect air exchange. If a house is built with lousy material that cannot absorb heat properly, it can change the temperature or increase the temperature and cause urban heat island. Urban heat island is a phenomenon that usually occurs in big cities where the temperature at night is hotter than the temperature in 
the morning due to heat reflection by building materials (Beta \& Wayan, 2019; Nuruzzaman, 2015).

Green open space also has a contribution due to implement the concept of sustainability in urban design nowadays. Sustainable urban design must be flexible and adapt to changing societies; if not, no one wants. Green open space also has a function in maintaining and preserving the equality of urban ecosystems, such as the environment, social and culture, so that green open space can act as the identity of the city, filtering out particles from the air, preserving groundwater and improving the city's aesthetics (Bambang, Murni, Defry, Setyo, 2019; Adriaens, 2005)

\section{Thermal Comfort}

Thermal comfort is a condition of the human mind that shows satisfaction with the thermal environment (Nugroho, 2011; Floriberta 2017). Olgyay (1963) in Floriberta (2017) defines a comfort zone as a zone where humans can reduce the energy that removed from the body in adapting itself to the surrounding environment. Based on ASHRAE, thermal comfort is a condition where there is satisfaction with the surrounding thermal conditions. This comfort is felt by the body when there is a thermal balance. Then the heat produced by the body is equivalent to the release and acquisition of heat in the body. According to Szokolay (1980), comfort influenced by several factors, namely air temperature, wind movement, air humidity, radiation, subjective factors, such as metabolism, clothing, food and drink, body shape, as well as age and sex. Climatological factors that influence thermal comfort are: Air temperature/temperature (C), Wind speed $(\mathrm{m} / \mathrm{s})$, Air humidity $(\% \mathrm{Rh})$, Solar radiation (watts/m2), Clothing insulation, Activities

Table 1.

The Average temperature and humidity of Pekalongan City in 2015.

\begin{tabular}{|l|l|l|l|l|l|l|}
\hline Month & $\begin{array}{c}\text { Temperature } \\
\text { Maks }\end{array}$ & $\begin{array}{c}\text { Temperature } \\
\text { Min }\end{array}$ & $\begin{array}{c}\text { Temperature } \\
\text { Average }\end{array}$ & $\begin{array}{c}\text { Humidity } \\
\text { maks }\end{array}$ & $\begin{array}{c}\text { Humidity } \\
\text { min }\end{array}$ & $\begin{array}{c}\text { Humidity } \\
\text { Average }\end{array}$ \\
\hline January & 32,8 & 24,80 & 28,80 & 93 & 72 & 83 \\
\hline February & 31,8 & 24,40 & 28,10 & 96 & 83 & 90 \\
\hline March & 32,80 & 24,70 & 28,75 & 91 & 79 & 85 \\
\hline April & 33,10 & 25 & 29,05 & 90 & 79 & 85 \\
\hline May & 33,40 & 24,70 & 29,05 & 87 & 72 & 80 \\
\hline June & 33,00 & 24,20 & 28 & 82 & 66 & 74 \\
\hline July & 32,4 & 23,50 & 27,95 & 84 & 68 & 75 \\
\hline August & 32,80 & 23,50 & 28,15 & 85 & 71 & 78 \\
\hline September & 34,00 & 24,20 & 29,10 & 80 & 64 & 72 \\
\hline October & 35,30 & 24,60 & 29,95 & 79 & 64 & 72 \\
\hline November & 35,80 & 25,80 & 30,80 & 86 & 70 & 78 \\
\hline December & 35,70 & 25,60 & 30,65 & 87 & 72 & 80 \\
\hline
\end{tabular}

In thermal comfort study Micro Climate is a specific weather condition on a building/site that is different from the climate in its zone. Climate can be modified or modified through site elements to form the terms of the temperature of the air humidity and wind speeds that produce thermal comfort (Nur, 2015). Site elements that make up the Climate Micro:

1. Topography, land surface shape mapped in the form of contour lines and surface relief, differences in elevation, slope, and shading effects can affect the distribution of solar thermal radiation, air temperature, and wind direction

2. Surface material, in the form of soil, stone, grass, and an artificial pavement made on site. Natural materials such as soil and green tend to have a lower albedo than artificial 
pavement such as concrete and brick, so natural materials are very suitable to be applied in public spatial planning.

3. Vegetation, can modify the climate into a microclimate in the following ways: Shading of sunlight through the canopy; as a surface material. The texture of the plant is rough. On the other hand, the direction of reflection scattered. Passive cooling where water vapor from plant respiration as it evaporates will take heat from the air; Angina barrier directors because the row of plants can direct or obstruct the motion of the wind; plants filter out wind-borne dust.

4. Surface water, water found on the surface of the plain. Helpful in the formation of a microclimate is to produce passive cooling.

\section{METHODOLOGY}

This research is an exploratory study with qualitative data collection (Fig. 1). The data processed of Jetayu Park to get more information about land size, microclimate including (air temperature, wind speed, to humidity) through observations, in-depth interviews. As for remarks made to assess the dimensions associated with physical elements (objective). While meetings for evaluating aspects related to social factors, as a result of the presence of the public space (subjective).

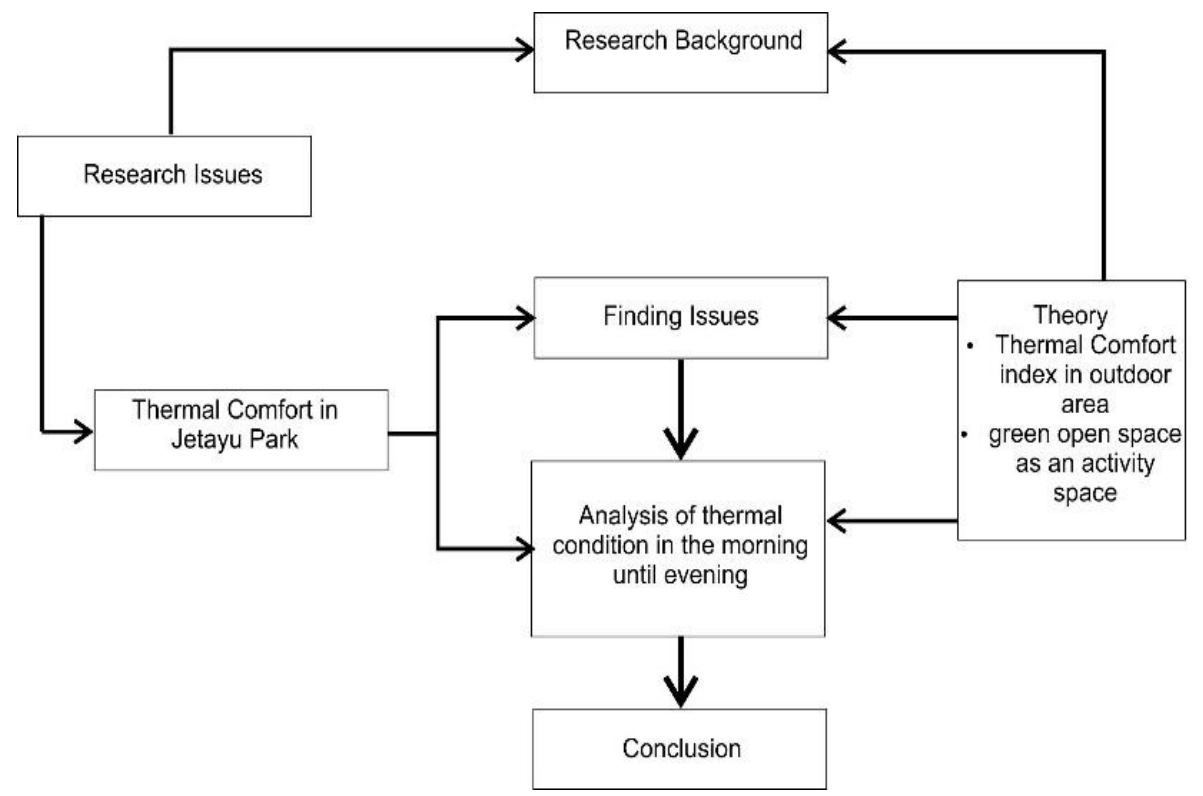

Fig. 1. Study flow chart.

\section{RESULTS AND DISCUSSIONS}

To find out the thermal conditions in the Jetayu area, measurements of air temperature, wind, and air humidity levels in this area taken. The results of field data measurements are as follows Figures 2 - 7. 


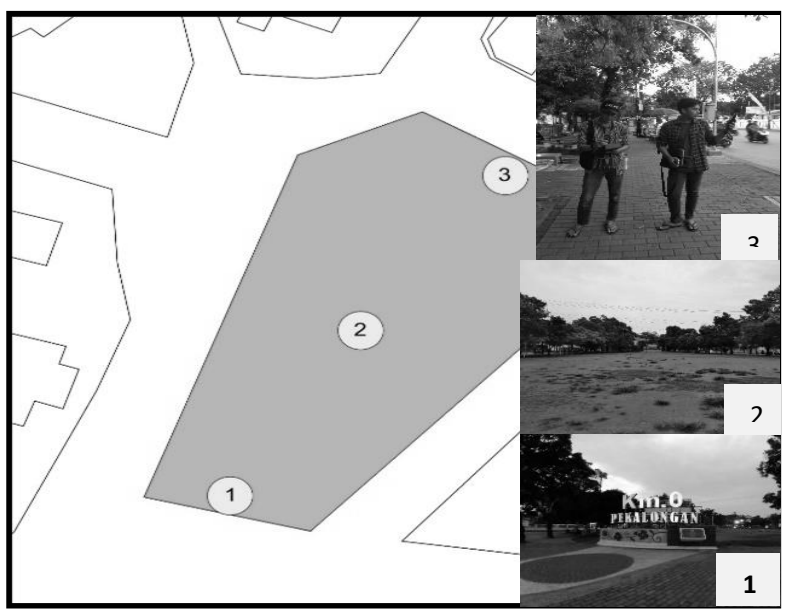

Fig. 2. Location of observation sites in the Jetayu Park.

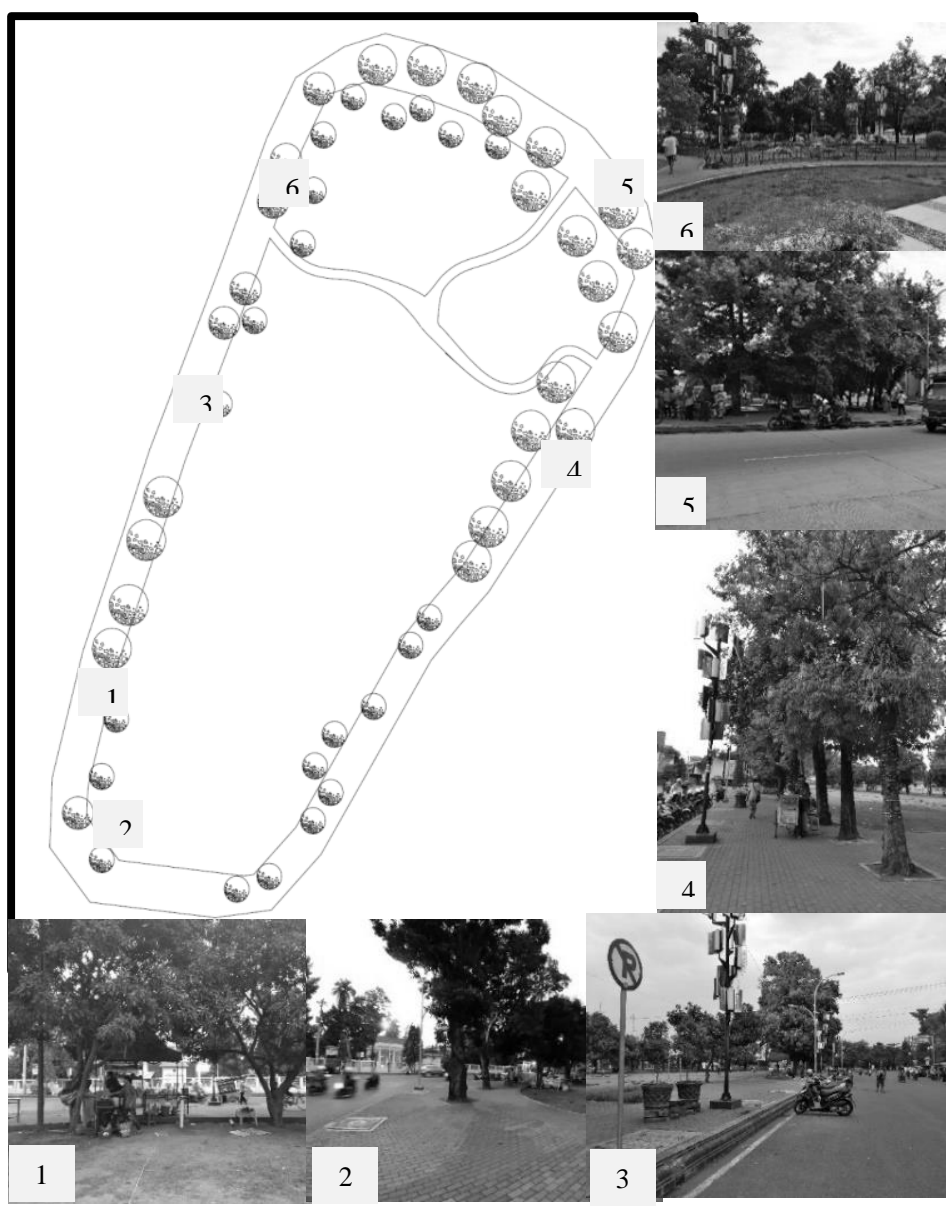

Fig. 3. The Eksisting of Jetayu Park. 


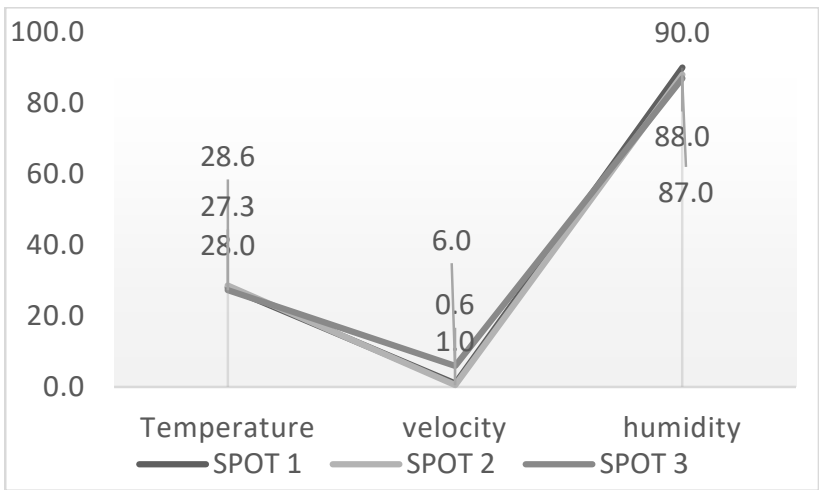

Fig. 4. conditions of Jetayu Park microclimate in the morning (06.00-07.00) Source: observation, 2019.

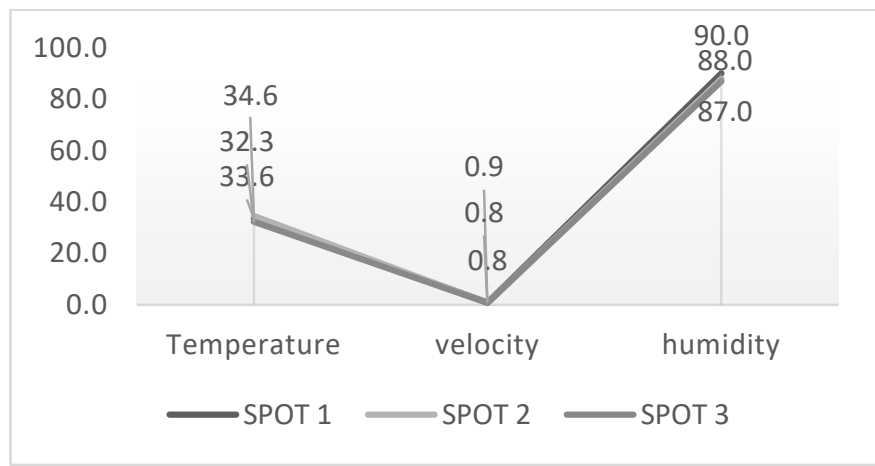

Fig. 5. conditions of Jetayu Park microclimate in the afternoon (11.00-12.00) Source: observation, 2019.

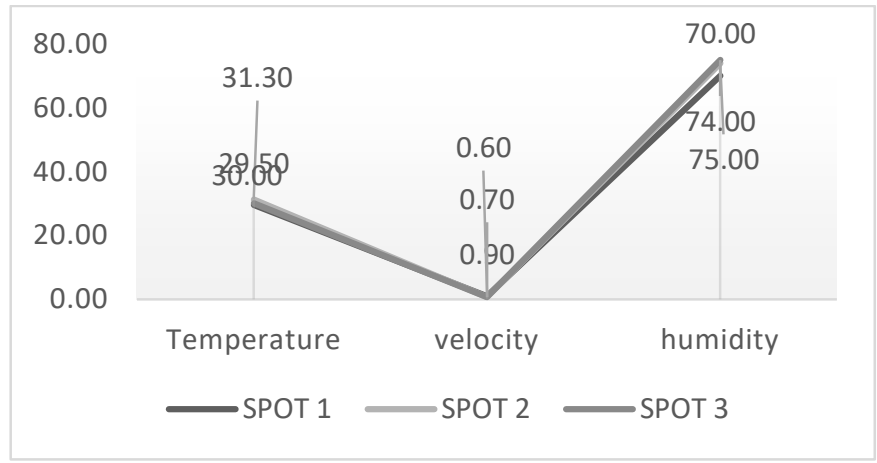

Fig. 6. conditions of Jetayu Park microclimate in the late afternoon (16.00-17.00) Source: observation, 2019. 


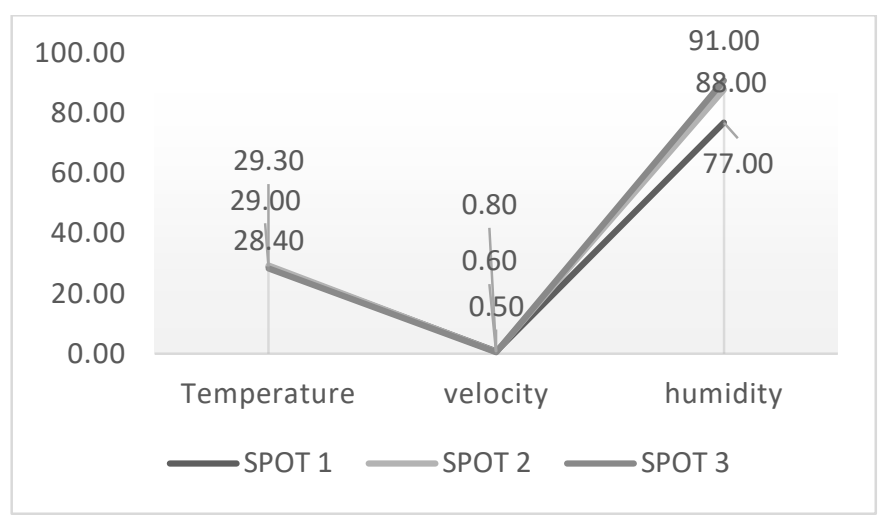

Fig. 7. conditions of Jetayu Park microclimate in the evening (21.00-22.00)

Source: observation, 2019.

Table 2.

Comparison of the number of Jetayu Park users in each time zone.

\begin{tabular}{|l|l|}
\hline \multicolumn{1}{|c|}{ Observation Time } & \multicolumn{1}{c|}{ Number of user } \\
\hline Pagi (06.00-07.00) & $75-100$ \\
\hline Siang (11.00-12.00) & $0-25$ \\
\hline Sore (16.00-17.00) & $125-150$ \\
\hline Malam (21.00-22.00) & $75-100$ \\
\hline
\end{tabular}

Source: observation, 2019.

From the results of field observations (Tab. 2) and measurements obtained the following results:

1. In the morning, the Jetayu field was used maximally by the local community for activities such as exercising, selling food, having breakfast, or just sitting on a park bench.

2. During the day, the temperature changes significantly enough to more than $5^{\circ} \mathrm{C}$, so the impact on the use of open space is not optimal enough.

3. In the afternoon, there is a decreasing in air temperature, which impacts on thermal comfort, which is better than during the daytime.

4. At night the Jetayu field is still quite busy with activities because the temperature at night is also quite useful for outdoor activities

5. The most crowd use of Jetayu Park occurs in the afternoon at exactly 16:00 to 17:00, while the lowest intensity of space usage occurs during the daytime.

\section{CONCLUSIONS}

The result of this observation is related to the theory of thermal comfort. Then, it shows in this Park cannot be used during the day, and Jetayu park has not fulfilled the thermal comfort yet. Creating a public green open space to help to control the microclimate certainly requires comprehensive planning, starting from considering the thermal conditions of the area to choosing the type of greening that will be used as a filler element for the city park along with other amenities. This study shows the thermal conditions of the Jetayu Park during 
the day showed quite high air temperatures at 34.6 C in Spot B, where is located in the middle of the park, which is part of the location without greening. At certain times even the air on the Envirometer moves up to $36 \mathrm{C}$, which in these conditions makes no one doing activities in the middle of this city park. Changes in air temperature have a significant effect on Jetayu park use activities. Besides, the existence of open space with trees also affects the distribution of its activities. With the increase in air temperature, the center of activity in this park will move in the part of the park that has shade trees and shown in spot 3 . The condition also indicates the influence of the number of food traders more in spot three than in other places. Therefore, if the Pekalongan city government wants to make the Jetayu Park an active open space throughout the day, it is necessary to consider designing a green open space that adjusts to the thermal conditions in this area.

\section{R E F E R E N C ES}

Alkadri; Windriarti H; Ati Widiati; Aphang S. (2014) Designing Creative Public Spaces in Pekalongan City. Policy Assessment Center for Competitiveness Enhancement Agency for the study and application of technology.

Amirhosein Ghaffarianhoseini, Umberto Berardi, Ali Ghaffarianhoseini, Karam Al-Obaidi (2019) Analyzing the thermal comfort conditions of outdoor spaces in a university campus in Kuala Lumpur, Malaysia. Science of the Total Environment Journal Vol 666.

Bambang Soemardiono, Murni Rachmawati, Defry Agatha Ardianta, Setyo Nugroho (2019) Spatial analysis of urban dense area in developing criteria design based on people participation: Case study of kembang jepun, surabaya. Geographia Technica, 14, Special Issue, 13-21.

Beta Paramita, Wayan Suparta (2019) Alteration of Urban Microclimate in Bandung, Indonesia Based on Urban Morphology. Geographia Technica, 14, Special Issue, 213-220

Floriberta Binarti; Hanson E. Kusuma; Surjamanto Wonorahardjo; Sugeng Triyadi (2017) The Effect of the Elements of Urban Space on the Thermal Comfort Level of Open Space: Between Theory and Perception, Proceeding of Scan\#8 Universitas Atma Jaya Yogyakarta. Yogyakarta. ISBN: 978-602-8817-84-4

Irfandi; Mirza; Irzaidi; Khairul Huda (2017) Effect of Physical Quality on Urban Active Open Spaces on the Quality of Life of Communities. Proceeding of Temu Ilmiah IPLBI.

Ni Wayan Meidayanti Mustika; I Wayan Wirya Sastrawan (2017) Perception of Outdoor Thermal Comfort Levels in Public Spaces (Case Study: City Park I Gusti Ngurah Made Agung) UNDAGI Jurnal Arsitektur Warmadewa, 5, (1), Tahun 2017, 45-56 ISSN 2338-0454

Nur Laela Latifah (2015) Book of Building Physic Chapter 1. Griya Kreasi Jakarta.

Santi, Siti Belinda, Hapsa Rianty (2017) Identification of UHI Potential on Green Open Space and Thermal Comfort in Mayor's Park in Kendari City. Proceeding of Temu Ilmiah IPLBI.

Suthat Yiemwattana, Sasima Charoenkit (2019) Towards An Engaging, Inclusive And Meaningful Planning Development Of An Urban Park In Phitsanulok, Thailand. Geographia Technica, 14, Special Issue, 76-86.

Teresa Zölcha; Mohammad A. Rahmana, Elisabeth Pfleiderera, Georg Wagnera, Stephan Pauleita (2018) Designing public squares with green infrastructure to optimize human thermal Comfort. Building and Environment Book. Technical University of Munich, Germany.

Tri Harso Karyono (2010) Thermal Comfort in Tropical Architecture. Architecture and Third World Tropical Cities: A Discussion of Indonesia. PT Raja Grafindo.

https://regional.kompas.com/read/2019/07/31/21553881/way-city-government-surabaya-loweringtemperature-air-2-degree-celcius. Contributor : Ghinan Salman

http://jateng.tribunnews.com/2018/03/29/serious-this-public-space-to-be-done-Pekalongan-City. Contributor: budi susanto. 